\title{
Morphometric Examination of Red Fox (Vulpes vulpes) from the Van-Yoncatepe Necropolis in Eastern Anatolia
}

\author{
Examen Morfométrico del Zorro Rojo (Vulpes vulpes) \\ de la Necrópolis de Van-Yoncatep en Anatolia del Este \\ "Vedat Onar; " Oktay Belli \& ${ }^{* * *}$ Pamela R. Owen
}

ONAR, V.; BELLI, O. \& OWEN, R. P. Morphometric examination of red fox (Vulpes vulpes) from the Van-Yoncatepe necropolis in Eastern Anatolia. Int. J. Morphol., 23(3):253-260, 2005.

SUMMARY: In the burial chamber M4 of the Van-Yoncatepe necropolis in eastern Anatolia, dated to the beginning of the first millennium before our time, fox skeletal remains have been discovered together with human skeletal remains. The fox remains consist of two skulls and a large number of skeletal (postcranial) bones. Examination of the material led us to the conclusion that five foxes had been buried in the chamber. Craniometric and osteometric measurements were carried out on the bones, and estimations of shoulder height and body weight have been calculated. Evaluation of all quantitative and qualitative data and comparison with modern fox species led to identification of the remains as red fox (Vulpes vulpes).

KEY WORDS: Morphometry; Red fox; Van-Yoncatepe; Vulpes vulpes.

\section{INTRODUCTION}

The Van-Yoncatepe settlement area (has been dated to the beginning of the first millennium before our time) is located $15 \mathrm{~km}$ southeast of Tushpa (Tuspa), the capital of Urart (also known as the rock cliffs of Van Castle), and 9 $\mathrm{km}$ southeast of the modern city of Van. At an altitude of $2051 \mathrm{~m}$ above sea level it is at present the highest excavation site in Turkey (Belli \& Konyar, 2001a,b, Belli \& Onar, 2003).

Unlike all the other burial chambers (chamber M5 and M6) at the Yoncatepe necropolis (Onar et al., 2002), chamber M4 contained the skeletal remains of several foxes (Vulpes sp.). It has been reported that all remains in chamber M4, which has a pre-entrance chamber design, had been buried in the main southern burial room. The grave had been carefully covered with large and heavy slabs made from sedimentary rock (Belli \& Konyar, 2001a).

The Yoncatepe necropolis is not the first archaeological site in Anatolia where canine remains have been discovered (Lawrence, 1967,1980; Clutton-Brock, 1970; Hongo, 1997, 1998; Martin \& Russell, 1997; Russell
\& Martin, 1998; Hongo \& Meadow, 2000). Notably, we report for the first time, fox remains in a separate burial arrangement in Anatolia. At the archaeological sites of Kaman-Kalehöyük, Çatalhöyük (central Anatolia) and Çayönü (southeastern Anatolia) bones of domesticated animals had been discovered among other faunal remains together with a small number of fox bones (Hongo, 1997, 1998; Martin \& Russell; Russell \& Martin; Hongo \& Meadow, 2000). The fox bones in Kaman-Kalehöyük were identified as those of the red fox (Vulpes vulpes) (Hongo, 1997, 1998) while the bones discovered in Çatalhöyük and Çayönü could only be referred to the genus Vulpes (Martin \& Russell; Russell \& Martin; Hongo \& Meadow). Analyses of the fox remains discovered at the latter archaeological site did not, however, include any morphometric data. Analyses of the faunal remains were restricted to qualitative statements that they were fox bones.

In this study we completed a detailed osteometric analysis of the fox skeletal remains from burial chamber M4 of the Van-Yoncatepe necropolis. We compared our

* Osteoarchaeology Laboratory of Department of Anatomy, Faculty of Veterinary Medicine, Istanbul University, 34320, Averlar, Istanbul, Turkey.

** Department of Ancient History, Faculty of Letters, Istanbul University, 34459, Beyazıt, Istanbul, Turkey.

*** Vertebrate Paleontology Laboratory, The University of Texas at Austin, 10100 Burnet Rd., Bldg 6, Austin, Texas, 78758, U.S.A.

This work was supported by the Research Fund of Istanbul University (Project number BYP-180/19032003). 
data with those from modern foxes in support of the reconstruction of their morphological appearance. The fox remains not only provide a record of species distribution in the Van region during the Early Iron Age, but also contribute to an elucidation of the particularities of burial chamber M4.

\section{MATERIAL AND METHOD}

During the 2002, excavation season human remains were discovered together with fox bones and in burial chamber M4. The chamber has been dated to the beginning of the first millennium before our time (Belli \& Konyar, 2001a,b). The fox remains consist of two skulls and a large number of skeletal bones.

The fox skeletal remains were carefully recovered and transferred to the Faculty of Veterinary Medicine, Department of Anatomy at Istanbul University. There the bones were sorted, classified and examined. The skeletal remains of the foxes were separated in two groups: cranial and skeletal (postcranial) bones. For cranial evaluation the two skulls were examined. Ontogenetic age estimation and sex determination of the two individuals was conducted by comparison, utilizing qualitative and quantitative character information from modern samples of Vulpes vulpes (Churcher, 1960; Lynch, 1996). Craniometric measurements were taken following the methodology of von den Driesch (1976). In order to be able to compare the results with other published data (e.g., Storm et al., 1976; Lynch; Temizer, 2001) a wide range of craniometric measurements were taken.

The above craniometric measurements (Figs. 1 and 2) were used to calculate the following indices and ratios: 1. Skull index, 2. Cranial index, 3. Facial index, 4. Facial index-1, 5. Facial index-2, 6. Basal index, 7. Basal index1, 8. Palatal index-1, 9. Palatal index-2, 10. Palato-basal ratio, 11. Palato-basal ratio-1, 12. Palato-palatin ratio, 13. Palato-palatin ratio-1, 14. Cranio-facial ratio, 15. Craniofacial ratio-1, 16. Length-length index-2, 17. Length-width index-2, 18. Length-width index-4, 19. Index-1, 20. Index2, 21. Postorbital index, 22. Foramen magnum index, 23. Snout index

Examination of the postcranial elements included measurements of humerus, radius, ulna, femur and tibia. For all other skeletal elements only their presence and number was recorded. On the basis of the long bone measurements, estimations of shoulder height and body weight of the fox species discovered in burial chamber M4 were made following the methodologies in Harcourt (1974), Anyonge (1993) and Wroe et al. (1999). For the calculation of the shoulder height, the factors (coefficients) suggested by Harcourt were used. The osteometric measurement of the long bones, which were used to calculate shoulder height and body weight, was based on the methods proposed by von den Driesch.

\section{Limb bone descriptive statistics (measurements in mm):}

Greatest length (GL); Mid-shaft diameter (MSD): MSD taken at a midpoint on the long axis of the bone (*MSD taken at a point $35 \%$ back from distal end of the humerus); Mid-shaft circumference (MSC): MSC taken at a midpoint on the long axis of the bone. (*MSC taken at a point $35 \%$ back from distal end of the humerus).

For the determination of body weight, the humeral and femoral mid-shaft circumference measurements were used and the calculation carried out with the aid of equations proposed by Anyonge for the calculation of the body weight of carnivores. The Anyonge equations were employed with due consideration of the application-related explanations provided by Wroe et al. The following formulae, proposed by the latter, were used:

Weight in grams $=10^{(2.88 \times \log (\mathrm{f}))-3.4}$

Weight in grams $=10^{(2.47 \times \log (\mathrm{h}))-2.72}$

$\log (f)$ : femoral circumference taken at the midpoint on the long axis.

$\log (\mathrm{h})$ : humeral circumference taken at a point $35 \%$ back from the distal end of the humerus.

The following explanation given by Wroe et al. was taken into consideration when applying the formulae:

"Anyonge's equations give estimates based on femoral and humeral circumference data independently. . - Corrections for logarithmic transformation bias could not be performed on these results because Anyonge (1993) did not present necessary raw data, i.e. femoral and humeral circumference values for the specimens included in his analysis. Consequently, these are likely to represent underestimates, as the logarithmic transformation bias value can not be less than 1.0 (Smith, 1993)"

The data on the external morphology of the fox specimens discovered in one burial chamber at the VanYoncatepe necropolis, which were obtained as a result of all evaluations, were compared with data from modern fox species. 
Fig. 1. Skull measurements.
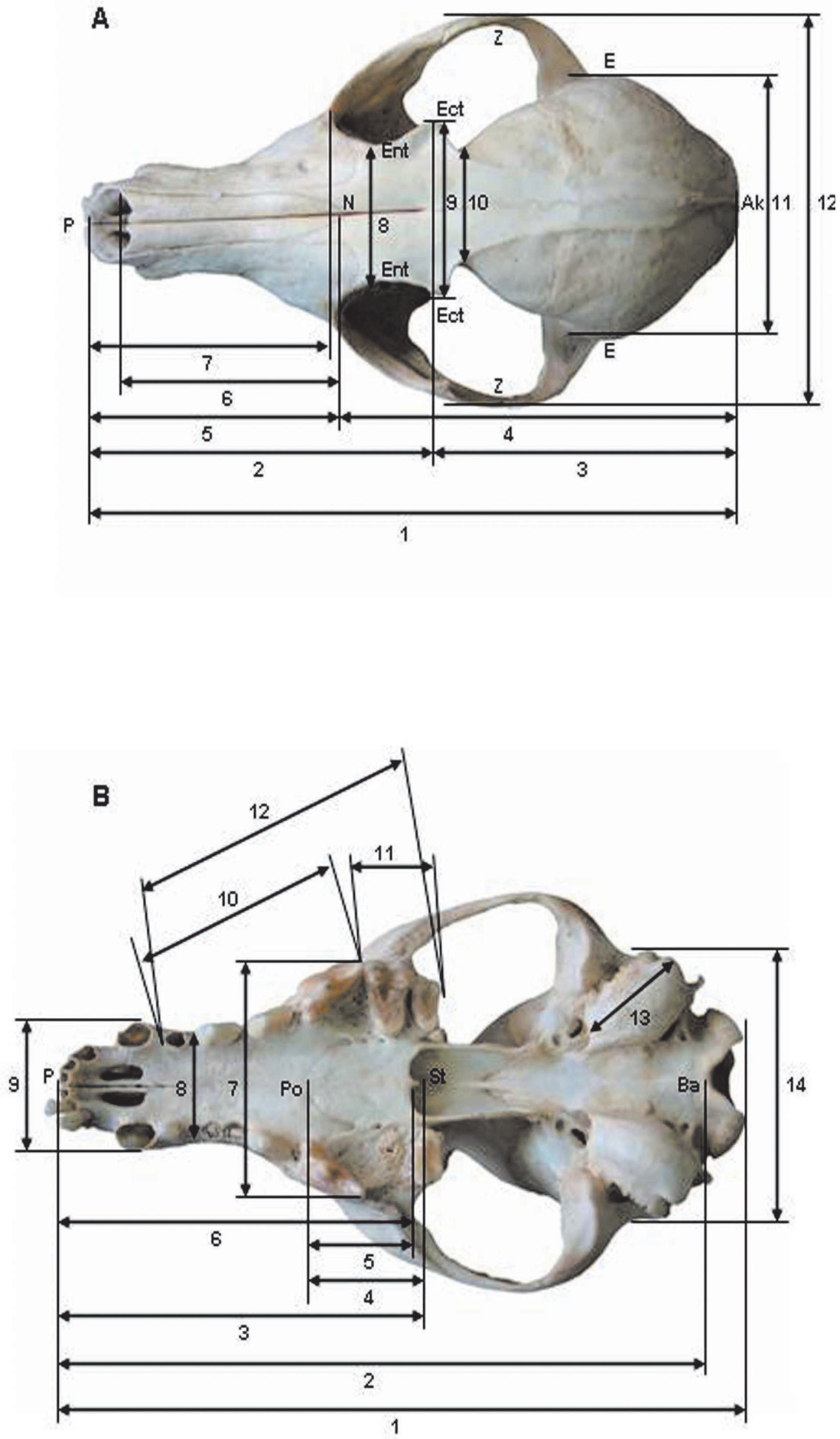

A. Dorsal view:

1. Skull length, 2. Facial length, 3. Upper neurocranium length, 4. Cranial length, 5. Viscerocranial length, 6. Greatest length of the nasals, 7. Snout length, 8. Least breadth between the orbits, 9. Frontal breadth, 10. Least breadth of skull, 11. Maximum width of neurocranium, 12. Maximum zygomatic width, Ak. Akrokranion, E. Euryon, Ect. Ectorbitale, Ent. Entorbitale, N. Nasion, P. Prosthion, Z. Zygion.

B-Ventral view:

1. Condylobasal length, 2. Basal length, 3. Median palatal length, 4. Length of the horizontal part of the palatine, 5. Length of the horizontal part of the palatine-1, 6. Palatal length, 7. Greatest breadth of the palatine (P4 level), 8. Least palatal breadth, 9. Breadth at the canine alveoli, 10. Length of the premolar row, 11. Length of the molar row, 12. Length of the cheektooth row, 13. Greatest diameter of the auditory bulla, 14. Breadth dorsal to the external auditory meatus, Ba. Basion, P. Prosthion, Po. Palatinoorale, St. Stayphylion. 


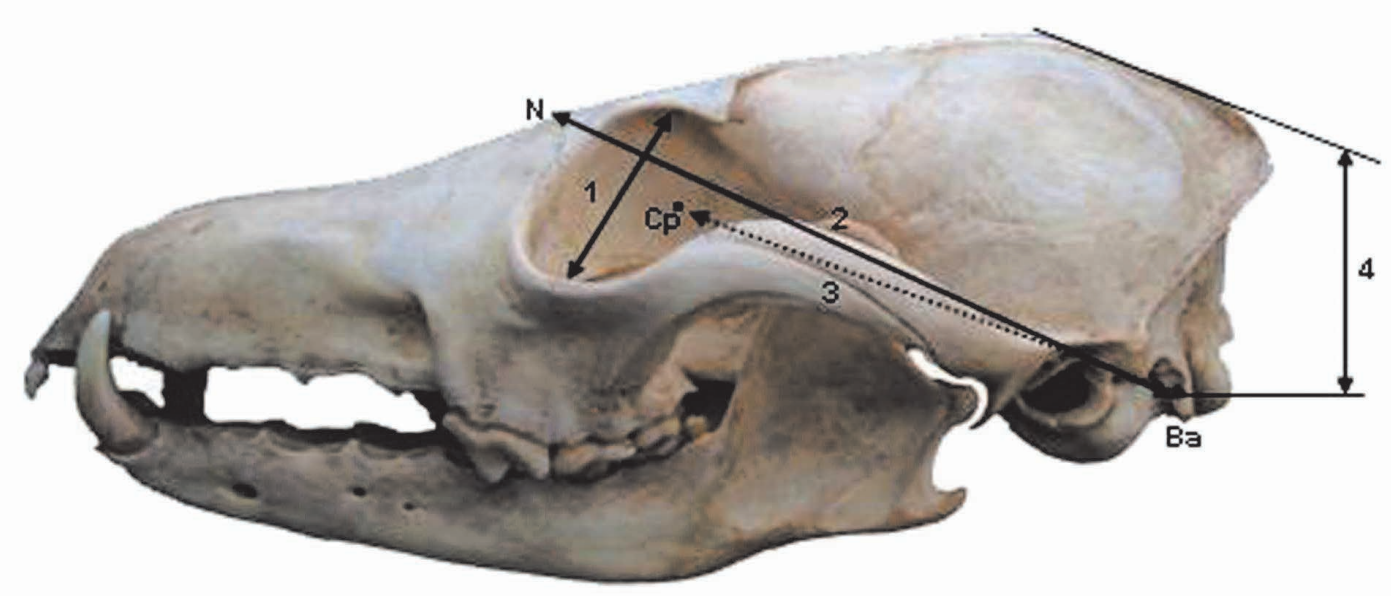

A. Left-Lateral view:

1. Greatest inner height of orbit, 2. Neurocranium length, 3. Braincase length, 4. Skull height, Ba. Basion, Cp. Cribriform plate, N. Nasion

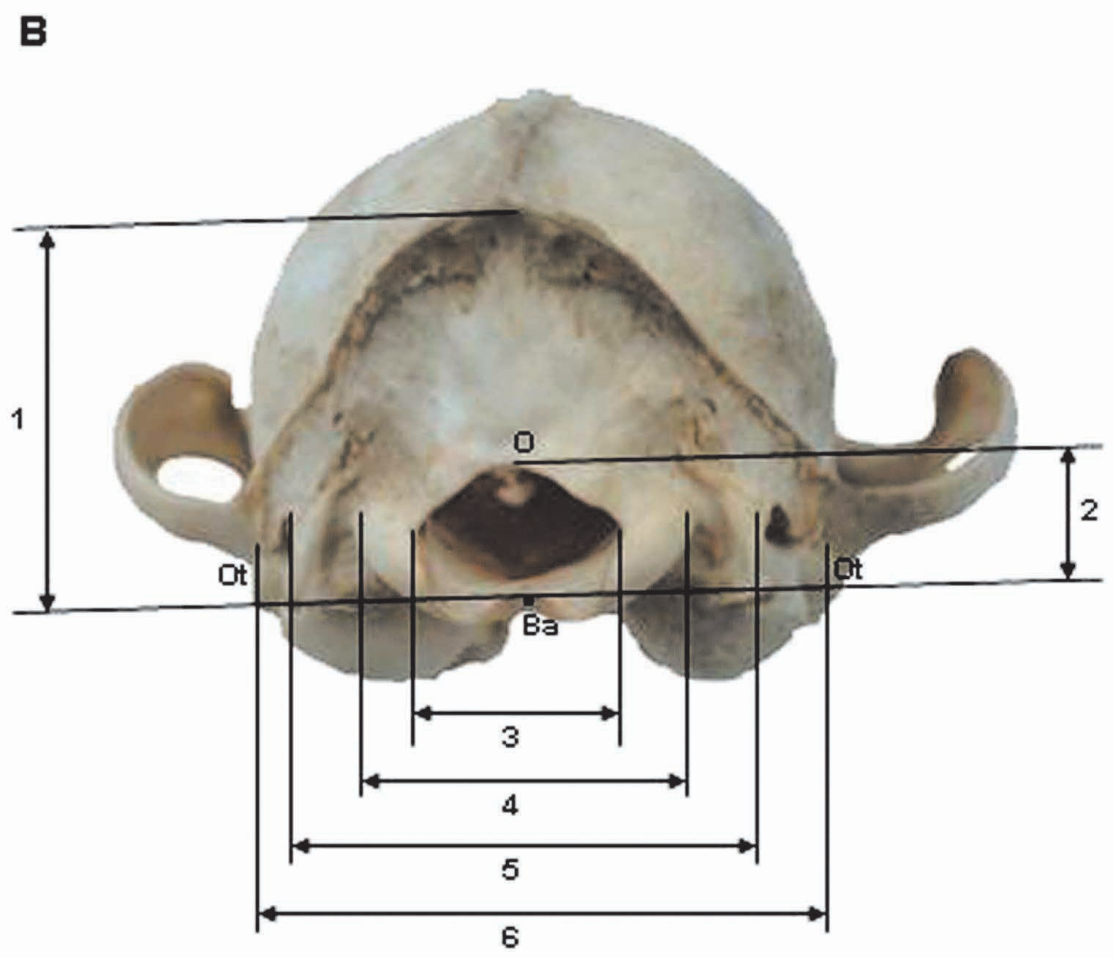

B. Occipital view:

1. Height of the occipital triangle, 2. Height of the foramen magnum, 3. Maximum width of the foramen magnum, 4. Maximum width of occipital condyles, 5. Greatest breadth of the bases of the jugular process, 6. Greatest mastoid breadth, Ba .Basion, O. Opisthion, Ot. Otion. 


\section{RESULT AND DISCUSSION}

The macro-anatomical examination of the skeletal remains discovered in burial chamber M4, does not reveal any deformation that may have occurred at the burial site. The bones had been preserved without any destruction up to the present day. A list of all bones unearthed in the burial chamber has been given in Table I.

Table I. Skeletal bones from burial chamber M4

\begin{tabular}{|c|c|}
\hline Bone & Total number \\
\hline Skull & 2 \\
\hline Mandible & 4 \\
\hline Scapula & 3 \\
\hline Humerus & 4 \\
\hline Radius & 4 \\
\hline Ulna & 4 \\
\hline Pelvis & 4 \\
\hline Femur & 7 \\
\hline Tibia & 4 \\
\hline Fibula & 1 \\
\hline Metacarpus/Metatarsus & 20 \\
\hline Atlas & 2 \\
\hline Axis & 3 \\
\hline Cervical vertebrae $3,4,5$ & 8 \\
\hline Cervical vertebra 6 & 2 \\
\hline Cervical vertebra 7 & 2 \\
\hline Thoracic vertebrae & 10 \\
\hline Lumbar verte brae & 13 \\
\hline Caudal vertebrae & 13 \\
\hline Os sacrum & 2 \\
\hline Sternebrae & 3 \\
\hline Phalanges & 18 \\
\hline Calcaneus (fibular tarsal bone) & 2 \\
\hline Talus (tibial tarsal bone) & 2 \\
\hline Tarsal bones & 2 \\
\hline Ribs (Costa) & 31 \\
\hline
\end{tabular}

Analysis of the skulls and skeletal bones discovered in burial chamber M4, led us to the conclusion that a total of five adult foxes had been buried in the chamber. However, only two skulls could be discovered in the chamber. Examination of the skulls and the skeletal bones resulted in referral of the canid remains in chamber M4 to red fox (Vulpes vulpes).

To support the initial species identification, estimations of body weight and shoulder height were made. For this purpose measurements of humerus, radius, ulna, femur and tibia were used. Body weight and shoulder height calculated on the basis of osteometric measurements (assuming that the limb bones were correctly attributed to different individuals) are summarised in Table II. The body weight of the five animals range between $5.126 \mathrm{~kg}$ and 7.655 $\mathrm{kg}$ and shoulder heights ranged between $34.89 \mathrm{~cm}$ and 41.99 $\mathrm{cm}$. The calculated body weight and shoulder heights were compared with data from modern fox species (Table III).

Age determination was based on dental development, state of dental attrition, and epiphyseal closure of cranial and skeletal bonesutures. The examination revealed that all skulls and skeletal bones belong to fully grown individuals. With respect to the state of dental attrition, fox T1 seems to be a little older than fox $\mathrm{T} 2$.

Taking certain geographic variations into account, sex determination of the two skulls was attempted. It is assumed that fox $\mathrm{T} 1$ is most likely female, while fox $\mathrm{T} 2$ is almost certainly male.

In order to obtain the craniometric data of the skulls and to be able to compare them with subspecies of Vulpes vulpes in Turkey, 39 craniometric measurements were taken. Using these craniometric measurements a total of 23 indices and ratios were calculated (Table IV).

Table II. Range of estimated shoulder height and body weight of red foxes (Vulpes vulpes) unearthed from burial chamber M4.

\begin{tabular}{lcccccc}
\hline Bone & $\mathbf{n}$ & GL & MSD & MSC & ESH (cm)* & EBW (kg)** \\
Humerus & 4 & $115.16-29,05$ & $7.18-8,20$ & $24.62-28,78$ & $36.85-\mathbf{4 1 , 6 1}$ & $5.206-\mathbf{7 , 6 5 5}$ \\
Radius & 4 & $105.52-23,55$ & $7.55-8,98$ & - & $35.51-41,24$ & - \\
Ulna & 4 & $123.66-44,77$ & - & - & $35.00-40,87$ & - \\
Femur & 7 & $115,24-36,50$ & $7,56-9,27$ & $26,73-30,63$ & $\mathbf{3 4 , 8 9 - 4 1 , 5 7}$ & $\mathbf{5 , 1 2 6 - 7 , 5 8 8}$ \\
Tibia & 4 & $130.23-47,57$ & $7.32-8,82$ & - & $38,97-44,03$ & - \\
\hline
\end{tabular}

$\mathrm{GL}=$ Greatest length $; \mathrm{MSD}=$ Mid-shaft diameter $; \mathrm{MSC}=$ Mid-shaft circumference $;$ *SH $=$ Shoulder height estimation after Harcourt (1974); **EBW = Body weight estimation after Anyonge (1993) and Wroe et al. (1999).

Bold type identifies minimum and maximum values for each bone. 
Table III. Estimated shoulder height and body weight of red foxes (Vulpes vulpes) recovered from burial chamber M4 compared with values for selected extant fox species according to various authors.

\begin{tabular}{|c|c|c|c|c|c|c|c|c|c|c|c|}
\hline & \multicolumn{10}{|c|}{$\begin{array}{c}\text { Estimated body } \\
\text { Weight (kg) }\end{array}$} & $\begin{array}{c}\text { Shoulder height } \\
\text { (cm) }\end{array}$ \\
\hline $\mathrm{T} 1$ & \multicolumn{10}{|c|}{5.409} & 36.61 \\
\hline $\mathrm{T} 2$ & \multicolumn{10}{|c|}{7.533} & 41.99 \\
\hline T3 & \multicolumn{10}{|c|}{6.079} & 38.20 \\
\hline T4 & \multicolumn{10}{|c|}{5.126} & 34.89 \\
\hline \multirow[t]{2}{*}{ T5 } & \multicolumn{10}{|c|}{6.335} & 38.68 \\
\hline & 1 & 2 & 3 & 4 & 5 & 6 & 7 & 8 & 9 & 10 & 5 \\
\hline Vulpes vulpes (Red fox) & $3.0-14.0$ & & $8.0-10.0$ & 4.0 & $3.0-11.0$ & & & & & & $35.0-40.0$ \\
\hline Male & & 4.5-5.4 & & & 6.7 & & & & & & \\
\hline Female & & 4.1-4.5 & & & 5.4 & & & & & & \\
\hline Vulpes corsac (Corsac fox) & & & & & & & & & & & unknown \\
\hline Vulpesferrilata (Tibetan fox) & & & & & & 7.0 & & & & & unknown \\
\hline Vulpesca: $a$ (Blanford's fox) & & & & 1.2 & & & $0.9-1.3$ & $710.0-956.0^{\prime \prime}$ & & & $28.0-30.0$ \\
\hline Vulpes velox velox (Swift fox) & $1.8-3.0^{* * *}$ & & & & $1.8-3$. & & & & & & $18.0-35.0$ \\
\hline Vulpes velox macrotis (Kit fox) & & & & 2.0 & $1.8-3$. & & & & & & $18.0-35.0$ \\
\hline Male & & & & & & & & & 2.2 & & \\
\hline Female & & & & & & & & & 1.9 & & \\
\hline Vulpes bengalensis (Bengal fox) & & & & & 1.8-3. & & & & & $2.7-3.2$ & unknown \\
\hline Vulpes rueppelli (Rüppell's fox) & $1.5-3.0$ & & & & $1.2-3$. & & & & & & 30.0 \\
\hline Vulpes pallida (Pale fox) & $1.5-3.6$ & & & & $2.0-3$ & & & & & & 25.0 \\
\hline Vulpes chama (Cape fox) & 4.0 & & & 4.0 & 2.6 & & & & & & 36.0 \\
\hline Urocyon cinereoargenteus (Gray fox) & & & & 4.0 & 3.0-7. & & & & & & unknown \\
\hline Urocyon littoralis (Island grey fox) & & & & & $1.3-2$. & & & & & & $12.0-15.0$ \\
\hline Vulpeszerda (Fennec fox) & & & & 3.0 & $1.0-1$. & & & & & & $19.0-21.0$ \\
\hline Alopex lagopus (Arctic fox) & & & & 3.0 & & & & & & & $25.0-30.0$ \\
\hline Male & & & & & 3.8 & & & & & & \\
\hline Female & & & & & 3.1 & & & & & & \\
\hline Otocyon me galotis (bat-eared fox) & & & & 3.5 & & & & & & & unknown \\
\hline
\end{tabular}

*: grams, Mendelsshon et al., 1987; **: Males average larger than females; 1. Nowak, 1999; 2.Average weight in North American sample (Ables, 1975); 3.Weight in central European sample (Haltenorth \& Roth, 1968); 4. Wayne, 1993; 5. Ginsberg \& Macdonald, 1990; 6.Males weight up to 7 kg (Mitchell, 1977); 7. Geffen, 1990; 8. Mendelssohn et al., (1987); 9: McGrew, 1979; 10: Roberts, 1977.

Table IV. The indices and ratios of Fox T1 and Fox T2 recovered from burial chamber M4.

\begin{tabular}{lrr}
\hline & Fox T1 & Fox T2 \\
Skull index & 52.52 & 52.33 \\
Cranial index & 62.37 & 57.92 \\
Facial index & 114.23 & 112.15 \\
Facial index-1 & 82.12 & 77.39 \\
Facial index-2 & 87.54 & 89.17 \\
Basal index & 37.75 & 35.34 \\
Basal index-1 & 56.96 & 57.23 \\
Palatal index-1 & 56.52 & 54.11 \\
Palatal index-2 & 57.95 & 55.10 \\
Palato-basal ratio & 55.85 & 56.91 \\
Palato-basal ratio-1 & 54.47 & 55.88 \\
Palato-palatin ratio & 31.60 & 31.86 \\
Palato-palatin ratio-1 & 32.39 & 32.44 \\
Cranio-facial ratio & 121.38 & 119.56 \\
Cranio-facial ratio-1 & 157.48 & 153.35 \\
Length-length index-2 & 1.21 & 1.20 \\
Length-width index-2 & 1.90 & 1.91 \\
Length-width index-4 & 1.60 & 1.73 \\
Index-1 & 52.52 & 52.34 \\
Index-2 & 35.88 & 33.78 \\
Postorbital index & 40.62 & 46.57 \\
Foramen magnum index & 80.84 & 74.63 \\
Snout index & 45.98 & 46.67 \\
\hline
\end{tabular}

The craniometric measurements as well as the values for indices and ratios indicate that the skulls of fox $\mathrm{T} 1$ and fox $\mathrm{T} 2$ are closely related. Of the calculated indices and ratio values, skull index, length-length index-2 and index-2 values were compared with index values calculated on the basis of craniometric measurements employed in studies on subspecies of Vulpes vulpes in Turkey (Table V). Comparison revealed that with the exception of the lengthwidth index-2 all other values give a good fit.

The red fox has a very wide distribution in Eurasia and North America (Ginsberg \& Macdonald; Nowak; Larivière \& Pasitschniak-Arts, 1996) and is very common in Anatolia (Temizer). Besides their general classification, work on the determination of subspecies has also been carried out (Temizer). Taking into account that the area of the Yoncatepe necropolis is part of the region where these species are common today it seems reasonable to conclude that they have been living in this region since prehistoric times. Body weight and shoulder height which have been calculated on the basis of long bone measurements are in good agreement with the values established for modern red fox (Vulpes vulpes) data. Based on the geographic distribution and morphometric data of other fox species it is concluded that the remains in burial chamber M4 are those of red fox. We 
Morphometric examination of red fox (Vulpes vulpes) from the Van-Yoncatepe necropolis in Eastern Anatolia. Int. J. Morphol., 23(3):253-260, 2005.

Table V. The indices and body weight of T1 and T2 foxes unearthed from burial chamber M4 compared with values in current subspecies of red fox (Vulpes vulpes) in Turkey.

\begin{tabular}{|c|c|c|c|c|c|c|c|c|c|c|c|}
\hline & \multirow[t]{2}{*}{ T1 Fox } & \multirow[t]{2}{*}{ T2 Fox } & \multicolumn{2}{|c|}{$\begin{array}{l}\text { Vulpes vulpes } \\
\text { alpherakyi* }\end{array}$} & \multirow[b]{2}{*}{$\begin{array}{r}\text { Mean } \\
n=16\end{array}$} & \multicolumn{2}{|c|}{$\begin{array}{l}\text { Vulpes vulpes } \\
\text { caucasica* }\end{array}$} & \multicolumn{4}{|c|}{$\begin{array}{l}\text { Vulpes vulpes } \\
\text { anatolica* }\end{array}$} \\
\hline & & & $\begin{array}{r}\text { Male } \\
n=7\end{array}$ & $\begin{array}{r}\text { Female } \\
n=9\end{array}$ & & $\begin{array}{l}\text { Male } \\
\mathrm{N}=11\end{array}$ & $\begin{array}{r}\text { Female } \\
n=12\end{array}$ & $\begin{array}{r}\text { Mean } \\
n=23\end{array}$ & $\begin{array}{r}\text { Male } \\
n=4\end{array}$ & $\begin{array}{r}\text { Female } \\
n=3\end{array}$ & $\begin{array}{r}\text { Mean } \\
\mathrm{n}=7\end{array}$ \\
\hline SL & 52.52 & 52.33 & 51.99 & 51.45 & 51.72 & 51.22 & 52.14 & 51.68 & 51.17 & 53.73 & 52.45 \\
\hline LLI-2 & 1.21 & 1.2 & 1.92 & 1.94 & 1.93 & 1.95 & 1.92 & 1.94 & 1.95 & 1.86 & 1.91 \\
\hline $\mathrm{I}-2$ & 35.88 & 33.78 & 34.36 & 35.28 & 34.82 & 34.75 & 35.46 & 35.11 & 33.24 & 35.57 & 34.41 \\
\hline BW (kg) & 5.409 & 7.533 & 5.800 & 4.327 & 5.064 & 5.060 & 4.483 & 4.772 & 6.025 & 4.966 & 5.496 \\
\hline
\end{tabular}

SL. Skull index; LLI-2. Length-length index-2; I-2. Index-2; BW. Body weight *Calculated according to Temizer's (2001) measurements.

believe that the fox skull T1 belongs to a female and the skull T2 to a male animal. This conclusion is supported by the respective body weight data. The calculated data of skull index and index-2 give a good fit with data calculated for skulls of Anatolian fox subspecies (Temizer). The detailed osteometric measurements of the red fox skeletal remains in burial chamber M4 provide an opportunity to compare present day red foxes and archaeological fox remains. This will facilitate a more detailed analysis of the archaeological bone fauna in Anatolia with respect to historical periods and geographic distribution.

ACKNOWLEDGEMENTS. The authors would like to acknowledge their great debt to S. Esra Onar, for her assistance during the excavation in Van-Yoncatepe. This work was supported by the Research Fund of Istanbul University (Project number BYP-180/19032003).

ONAR, V.; BELLI, O. \& OWEN, R. P. Examen morfométrico del zorro rojo (Vulpes vulpes) de la necrópolis de Van-Yoncatepe en Anatolia del Este. Int. J. Morphol., 23(3):253-260, 2005.

RESUMEN: En la cripta mortuoria M4 del cementerio Van-Yoncatepe en Anatolia del Este, se encontraron restos de zorro y humanos que datan de mil años aC. Los restos de zorro corresponden a 2 cráneos y variados huesos postcraniales. Los estudios de dicho material nos lleva a concluir que, hubo 5 zorros enterrados en la cripta. Conjuntamente, se realizaron exámenes craniométricos y mediciones osteométricas, estimaciones de altura de hombro y cálculo de peso corporal. Las evaluaciones cuantitativa y cualitativa de la información obtenida y las comparaciones realizadas con especies de zorros modernos, permiten concluir que dichos hallazgos corresponden a zorro rojo (Vulpes vulpes).

PALABRAS CLAVE: Morfometría; Zorro rojo; Van-Yoncatepe; Vulpes vulpes.

\section{REFERENCES}

Ables, E. D. Ecology of the red fox in North America. In: Fox, M.W., ed. The Wild Canids. Von Nostrand Reinhold, New York, 1975.

Anyonge, W. Body mass in large extant and extinct carnivores. $J$. Zool. 231:339-50, 1993.

Belli, O. \& Konyar, E. Excavations of Van-Yoncatepe Fortress and Necropolis (1997-1999). In: Belli, O. eds. Istanbul University's Contributions to Archaeology in Turkey (1932-2000). Istanbul University Rectorate Publication, Istanbul, 2001a. pp. 150-6.

Belli, O. \& Konyar, E. Excavations at Van-Yoncatepe fortress and necropolis. Journal of the Institute of Archaeology of Tel Aviv University 28:169-219, 2001b.
Belli, O. \& Onar, V. Yoncatepe: Iron Age. ArkeoAtlas, 2:148-9, 2003.

Churcher, C. S. Cranial variation in the North American red fox. $J$. Mammal., 41:349-60, 1960.

Clutton-Brock, J. The Origin of the Dog. In: Brothwell, D. \& Higgs, E. eds. Science in Archaeology. Revised and Enlarged Ed., Praeger Publication, New York, 1970. pp. 303-9.

Geffen, E. The behavioural ecology of Blanford's fox, Vulpes cana. D. Phil. Thesis, University of Oxford, Oxford, 1990.

Ginsberg, J. R. \& Macdonald, D. W.; Foxes, Wolves, Jackals \& Dogs. An Action Plan for the Conservation of Canids. IUCN Publications, Gland, Switzerland, 166 pp, 1990. 
Haltenorth, T. \& Roth, H. H. Short review of the biology and ecology of the red fox. Saugetierkunde Mitteilungen, 16:339$52,1968$.

Harcourt, R. A. The Dog in Prehistoric and Early Historic Britain. J. Archaeol. Sci., 1:151-75, 1974.

Hongo, H. Patterns of animal husbandry, environment, and ethnicity in central Anatolia in the Ottoman Empire Period: Faunal remains from Islamic layers at Kaman-Kalehöyük. Japan Review, 8:275-307, 1997.

Hongo, H. Patters of Animal Husbandry at Kaman-Kalehöyük, Turkey: Continuity and Changes During The Second and First Millenia B.C. In: Mikasa, T., eds. Essays on Ancient Anatolia in the Second Millennium B.C., Harrassowitz Verlag, Wiesbaden, 1998. pp. 239-78.

Hongo, H. \& Meadow, R. H. Faunal remains from Prepottery Neolithic levels at Çayönü, Southeastern Turkey: A preliminary report focusing on pigs (Sus sp.). ICAZArchaeozoology of the Near East IV A. Proceedings of the fifth international symposium on the archaeozoology of southwestern Asia and adjacent areas. Mashkour, M., Choyke, A.M., Buitenhuis, H., Poplin, F., eds. ARC-Publicatie 32: Groningen, The Netherlands, 2000. pp. 121-40.

Larivière, S. \& Pasitschniak-Arts, M. Vulpes vulpes. Mamm. Species, 537:1-11, 1996.

Lawrence, B. Early domestic dogs. Sonderdruck aus Zeitschrift für Säugetierkunde, 32:44-59, 1967.

Lawrence, B. Evidences of animal domestication at Çayönü. In: Çambel, H. \& Braidwood, R. J., eds. The Joint Istanbul-Chicago Universities' Prehistoric Research in Southeastern Anatolia I. $\mathrm{N}^{\circ}$ 2589. Istanbul University, Faculty of Letters Press, Istanbul, 1980. pp. $285-308$

Lynch, J. M. Sexual dimorphism in cranial size and shape among red foxes Vulpes vulpes from North-east Ireland. Biology and Environment. Proceedings of the Royal Irish Academy 96B: 21-6, 1996.

Martin, L. \& Russell, N. Animal Bone Report. Çatalhöyük Archive Report. Çatalhöyük. Available from http://catal.arch.cam.ac.uk/ catal/Archive_rep97/martin97.html (Verified, 16 May 2005), 1997.

McGrew, J.C. Vulpes macrotis. Mamm. Species, 123:1-6, 1979.

Mendelssohn, H.; Yom-Tov, Y.; Ilany, G. \& Meninger, D. On the occurrence of Blanford's fox, Vulpes cana Blanford, 1877, in Israel and Sinai. Mammalia, 51:459-67, 1987.

Mitchell, R. M. Accounts of Nepalese mammals and analysis of the host-ectoparasite data by computer techniques. Ph.D. diss., Iowa State University, Iowa, 1977.
Nowak, R. M. Walker's Mammals of the World. 6th edition. The John Hopkins University Press, Baltimore, Maryland, 1999.

Onar, V.; Armutak, A.; Belli, O. \& Konyar, E. Skeletal remains of dogs unearthed from the Van-Yoncatepe Necropolises. Int. J. Osteoarchaeol., 12:317-34, 2002.

Roberts, T. J. The mammals of Pakistan. Ernest Benn, London, 1977. $361 \mathrm{pp}$.

Russell, N. \& Martin, L. Çatalhöyük Animal Report. Çatalhöyük Archive Report. Çatalhöyük. Available from http:// catal.arch.cam.ac.uk/catal/Archive_rep98/martin98.html (Verified, 16 May 2005), 1998.

Smith, R. J. Logarithmic transformation bias in allometry. Am. J. Phy. Anthropol., 90:215-28, 1993.

Storm, G. L.; Andrews, R. D.; Phillips, R. L.; Bishop, R. A.; Siniff, D. B. \& Tester, J. R. Morphology, reproduction, dispersal, and mortality of midwestern red fox populations. Wildlife Monographs, 49:1-82, 1976.

Temizer, A. Taxonomic status of fox (Vulpes vulpes) subspecies in Turkey. Firat Univ. J. Sci. Engineer, 13:15-24, 2001.

Von den Driesch, A. A Guide to the Measurement of the Animal Bones from Archaeological Sites. Peabody Museum Bulletin 1. Harvard University, Massachusetts, 137 pp, 1976.

Wayne, R. K. Phylogenetic relationships of canids to other carnivores. In: Evans, H.E., eds. Miller's Anatomy of the Dog. 3rd edition. W.B. Saunders Company, Philadelphia and London, 1993. pp. 15-21.

Wroe, S.; Myers, T. J.; Wells, R.T. \& Gillespie, A. Estimating the weight of the Pleistocene marsupial lion, Thylacoleo carnifex (Thylacoleonidae: Marsupialia): implications for the ecomorphology of a marsupial super-predator and hypotheses of impoverishment of Australian marsupial carnivore faunas. Aust. J. Zool., 47:489-98, 1999.

Correspondence to:

Dr. Vedat Onar

Osteoarchaeology Laboratory

Department of Anatomy

Faculty of Veterinary Medicine

Istanbul University

34320, Avcular, Istanbul

TURKEY

E-mail:onar@istanbul.edu.tr

Received: 26-05-2005

Accepted: 28-07-2005 